\title{
Regulation of cell wall remodeling in grapevine (Vitis vinifera L.) callus under individual mineral stress deficiency
}

\author{
João C. Fernandes ${ }^{a}$, Luis F. Goulao ${ }^{\mathrm{b}}$, Sara Amâncio ${ }^{\mathrm{a}, *}$ \\ a DRAT/LEAF, Instituto Superior de Agronomia, Universidade de Lisboa, Tapada da Ajuda, 1349-017 Lisbon, Portugal \\ b BioTrop, Instituto de Investigação Científica Tropical (IICT, IP), Pólo Mendes Ferrão-Tapada da Ajuda, 1349-017 Lisbon, Portugal
}

\section{A R T I C L E I N F O}

\section{Article history:}

Received 17 August 2015

Received in revised form 22 October 2015

Accepted 22 October 2015

Available online 1 December 2015

\section{Keywords:}

Cell wall polymers

Endoglucanase activity

Gene expression

Nutrient deficiency

Pectin desterification

\begin{abstract}
A B S T R A C T
Cell wall $(\mathrm{CW})$ is a dynamic structure that determines the plant form, growth and response to environmental conditions. Vitis vinifera callus grown under nitrogen $(-\mathrm{N})$, phosphorous $(-\mathrm{P})$ and sulfur $(-\mathrm{S})$ deficiency were used as a model system to address the influence of mineral stress in CW remodeling. Callus cells morphology was altered, mostly under $-\mathrm{N}$, resulting in changes in cell length and width compared with the control. CW composition ascertained with specific staining and immuno-detection showed a decrease in cellulose and altered pattern of pectin methylesterification. Under mineral stress genes expression from candidate families disclosed mainly a downregulation of a glycosyl hydrolase family 9C (GH9C), xyloglucan transglycosylase/hydrolases (XTHs) with predicted hydrolytic activity and pectin methylesterases (PMEs). Conversely, upregulation of PMEs inhibitors (PMEIs) was observed. While methylesterification patterns can be associated to PME/PMEI gene expression, the lower cellulose content cannot be attributed to altered cellulose synthase (CesA) gene expression suggesting the involvement of other gene families. Salt extracts from $-\mathrm{N}$ and $-\mathrm{P}$ callus tissues increased plastic deformation in cucumber hypocotyls while no effect was observed with $-\mathrm{S}$ extracts. The lower endo-acting glycosyl hydrolase activity of $-\mathrm{N}$ callus extracts pinpoints a more expressive impact of $-\mathrm{N}$ on $\mathrm{CW}$-remodeling.
\end{abstract}

(C) 2015 Elsevier GmbH. All rights reserved.

\section{Introduction}

The primary plant cell wall $(\mathrm{CW})$ is a dynamic structure formed by a complex of inextensible cellulose microfibrils bonded to a network of coextensive glycans embedded in a pectin-rich gel matrix that includes structural glycoproteins, phenolic compounds and enzymes. CW plays a vital role in controlling the cell shape and, consequently, its morphology (Doblin et al., 2010; Cosgrove and Jarvis, 2012). Well-orchestrated CW alterations resulting from synthesis, disassembly, solubilization and rearrangements of its

Abbreviations: 2,4-D, 2,4-dichlorophenoxy-acetic acid; CesA, cellulose synthase; CMC, carboxymethylcellulose; CW, cell wall; EXP, expansin; EXPA, $\alpha$-expansin; GalA, galacturonic acid; GH9A, glycosyl hydrolase family 9A; GH9C, glycosyl hydrolase family 9C; HG, homogalacturonan; KOR, KORRIGAN; $-\mathrm{N}$, absence of nitrogen; -P, absence of phosphorous; PBS, phosphate buffered saline; PG, polygalacturonase; PL, pectate lyases; PME, pectin methylesterase; PMEI, pectin methylesterases inhibitor; PVP-40T, polyvinylpyrrolidone; $-\mathrm{S}$, absence of sulfur; XEH, endohydrolase activity of xyloglucan transglycosylase/hydrolases; XET, transglycosylase activity of xyloglucan transglycosylase/hydrolase; XTH, xyloglucan transglycosylase/hydrolase; XyG, xyloglucan.

* Corresponding author.

E-mail address: samport@isa.ulisboa.pt (S. Amâncio). structural components and linkages, are the basis of cell expansion and growth. Moreover, CWs represent one of the first levels of communication between the plant and surrounding environment, playing a decisive role in adaptation to biotic and abiotic pressures (Landrein and Hamant, 2013; Malinovsky et al., 2014; Tenhaken, 2015). CW changes relate to events such as localized cell division, arrestment of cell elongation and alterations in differentiation status, resulting in constraints that impact changes in anatomy and development (Potters et al., 2007; Braidwood et al., 2014).

The molecular regulation underlying CW dynamic behavior outcomes paradoxal effects in the contribution provided to the cell mechanical properties. Growing cells expand by CW loosening while, at the same time, enough strength is kept to retain the integrity and withstand high turgor forces. The control of CW loosening has been postulated to occur, at least in part, due to modifications in the cellulose-xyloglucan $(\mathrm{XyG})$ network linkages (McQueen-Mason and Cosgrove, 1995; Cosgrove, 2000; Whitney et al., 2000), was proved by Van Sandt et al. (2007). Recently Park and Cosgrove $(2012,2015)$ proposed that XyG is restricted to a minor component of the CW, closely intertwined with cellulose at limited sites, promoting selective targets for CW loosening, the so called "biomechanical hotspots" theory. Other modifications in the same network as well as in the pectin structure can, con- 
versely, result in CW stiffening and suppression of cell elongation (Takeda et al., 2002), also contributing to CW integrity and rigidity. In fact, hydrolysis of methyl ester bonds at GalA residues, leading to alterations in linear homogalacturonan (HG) domains, degree and pattern of pectin methyl esterification, significantly impacts CW biophysical properties (Peaucelle et al., 2008, 2011; Jolie et al., 2010).

The role of CW synthesis and modification has been investigated through quantification of related enzyme activity and gene expression and the enzyme biological function has been disclosed in genotypes impaired or overexpressing specific gene members (e.g., Osato et al., 2006; Peaucelle et al., 2008; Miedes et al., 2010).

In knocked-out cellulose synthase (CesA) Arabidopsis thaliana mutants an effective reduction in cellulose content was observed together with moderate abnormal growth (Desprez et al., 2007; Handakumbura et al., 2013) confirming other results on CesAs requirement for cellulose synthesis (Somerville, 2006; Endler and Persson, 2011). Nonetheless, CesA activity is insufficient to guarantee the correct formation of the network suggesting that the coordinated participation of other components is needed for cellulose synthesis, assemblage or deposition (Takahashi et al., 2009). Mutations impairing the expression of KORRIGAN (KOR), a class A $\beta$-1,4-endo-glucanase (GH9A) (Urbanowicz et al., 2007a), demonstrate the requirement of KOR for the correct assemblage in elongating cells (Nicol et al., 1998) since they show a significant reduction in cellulose content even when the expression of all CesA members was normal. This reduction was apparently compensated with increased pectin amounts and altered composition, particularly an increased glucose content (Sato et al., 2001). Recently Vain et al. (2014) showed that KOR is an integral part of the CesA complex. A role for a poplar class $C \beta$-1,4-endo-glucanase (GH9C) member in modulating cellulose crystallinity and its involvement in cell growth was recently demonstrated using reverse genetic approaches (Glass et al., 2015).

Regarding CW remodeling, expansins (EXP), proteins with the ability to cause loosening in in vitro assays (McQueen-Mason et al., 1992), are considered the major contributors, acting by reversible weakening interactions or disrupting hydrogen bonds between cellulose microfibrils and matrix-linked glycans (McQueen-Mason and Cosgrove, 1995; Cosgrove, 2000; Whitney et al., 2000; Wang et al., 2013). Among the expansin superfamily, $\alpha$-expansins (EXPA) are the foremost promoters in controlling cell extensibility in dicots (Cosgrove, 1999, 2000). As reviewed by Choi et al., (2006), genetic modification allowed associating EXPAs to cell enlargement and fruit softening among other effects on plant growth and development. Other members of CW enzyme families were further demonstrated to cause $\mathrm{CW}$ extensibility under in vitro conditions, namely some xyloglucan endotransglycosylases/hydrolases (XTHs) (Van Sandt et al., 2007) and endoglucanases (GHs) (Yuan et al., 2001; Park and Cosgrove, 2012). Tomato hypocotyls overexpressing or suppressed in a specific XTH produced respectively increased and decreased levels of soluble XET activity, and a positive correlation with CW extensibility and organ growth was observed (Miedes et al., 2010). With a specific Arabidopsis RNAisilenced XTH Osato et al. (2006) obtained a small but significant reduction in primary root cell elongation recently confirmed in Wilson et al. (2015) using multi-omics analysis. Similarly, also in Arabidopsis, the down-regulation of a specific class $C \beta-1,4-$ endo-glucanase (GH9C) led to weakening of the $\mathrm{CW}$ during root hair formation and growth (del Campillo et al., 2012). The regulation, pattern and extent of pectin de-esterification is controled by the activity of particular members of pectin methylesterases (PMEs) (reviewed by Goulao, 2010) and their interaction with specific inhibitors (PMEI) (Bellincampi et al., 2004; Di Matteo et al., 2005; Juge, 2006; Jolie et al., 2010) and therefore, are among the main enzymes to impact changes in biophysical properties of the CW. It is proposed that depending on the specific pattern and degree of methylesterification, pectins can aggregate into hydrated calcium-linked gel structures, that increase wall stiffness and reduce creep (Willats et al., 2001), or make pectins more susceptible to depolymerisation by polygalacturonases (PGs) and pectate lyases (PLs) hydrolysis contributing to CW relaxation (Brummell and Harpster, 2001; Wakabayashi et al., 2003). In Arabidopsis mutants over-expressing a PME or a PMEI, Peaucelle et al. $(2008,2011)$ observed respectively, decreased and increased pectin methylesterification, suggesting CW loosening is generated by PME activity. This assumption was confirmed in other works using Arabidopsis mutants impaired in PME activity with evidence of inhibition of cell elongation (Derbyshire et al., 2007) and reduction in the degree of methylesterification (Hongo et al., 2012). Models of $\mathrm{CW}$ architecture are supported by evidences for the presence of covalent bonds between pectin chains and cellulose microfibrils (Zykwinska et al., 2005, 2007; Park and Cosgrove, 2015) or matrixlinked glycans (Popper and Fry, 2005; Marcus et al., 2008) disclosing important ties in CW biochemistry and an under-looked role played by PMEs and PMEIs in CW mechanical properties. Furthermore, under conditions that drastically compromise the CW integrity, plant cells are known to trigger compensatory alternative mechanisms to its reinforcement via biosynthesis of new material or establishment of new linkages (Pilling and Höfte, 2003; Wolf et al., 2012), adding additional complexity to the fine-tuned process of CW responses to development-impacting stimuli.

Using Vitis vinifera callus as a model experimental system we recently showed that individual mineral deprivation leads to $\mathrm{CW}$ structural modifications (Fernandes et al., 2013), in particular a decrease in cellulose compensated by an increase in lignin content, and modifications in pectin methyl esterification. This suggests a specific level of control to produce a complex fine-tuned sensing mechanism to maintain CW integrity. Plant CW-modifying enzymes are present in large multigenic families (Lerouxel et al., 2006; Farrokhi et al., 2006), involving more than 2000 genes (Carpita et al., 2001) with distinct patterns of expression among cells and tissues.

To extend our previous results on the CW specific composition and arrangement modifications in response to individual mineral deprivation at molecular regulation level, a comprehensive in silico data mining was undertaken to retrieve the sequence of all identified members of $V$. vinifera candidate $C W$-modifying multigenic families and the expression of amplified sequences in callus was quantified. The potential loosening activity of salt extracts from callus growing under mineral deficiency was addressed and an extensometer-based experimental approach was used to evaluate in vivo mechanical modifications on dicot $\mathrm{CW}$ specimens.

\section{Material and methods}

\subsection{Callus culture and mineral stress imposition}

Callus tissues established from $V$. vinifera $\mathrm{cv}$. Touriga Nacional leaves were obtained as described in Jackson et al. (2001). Four explants with circa $4.5 \mathrm{~g}$ total weight per $9 \mathrm{~cm} \phi$ Petri dish were growing in MS basal salts medium (Murashige and Skoog, 1962) (DuchefaBiochemie, Haarlem, NL) supplemented with $2.5 \mu \mathrm{M}$ 2.4-D (2,4-dichlorophenoxy-acetic acid); $1 \mu \mathrm{M}$ kinetin; $5 \mathrm{~g} \mathrm{l}^{-1} \mathrm{PVP}-$ 40T; $20 \mathrm{gl}^{-1}$, sucrose; $2 \mathrm{~g} \mathrm{l}^{-1}$ Gelrite $^{\circledR}, \mathrm{pH} 5.7$, at $25^{\circ} \mathrm{C}$, in the dark. Following the experimental conditions described in Fernandes et al. (2013) callus tissue was sub-cultured every three weeks, for a total of 9 weeks. To obtain the samples under imposed mineral deficiency (mineral stresses), four treatments were applied: (i) MS complete medium (control), and (ii) nitrogen $(-\mathrm{N})$, (iii) phosphorus $(-\mathrm{P}),(\mathrm{iv})$ sulfur $(-\mathrm{S})$ deficient media, in which nitrates, phosphates 
and sulfates were replaced by chlorides. After each three week culture cycle in each treatment medium, samples corresponding to three Petri dishes were collected to monitor growth. Based on the results obtained, six weeks grown callus $(2 \times 3$ weeks $)$ were used immediately for microscopy studies or stored at $-80^{\circ} \mathrm{C}$ for subsequent extraction of protein salt extracts or RNA.

\subsection{Histological staining}

Samples of callus tissue were gently desegregated in PBS buffer and added with $2-3$ drops of $0.1 \%(\mathrm{w} / \mathrm{v}$ ) Calcofluor White fluorescent brightener (Sigma, St. Louis, MO) for cellulose detection. The material was then transferred to a microscope slide with a cover slip and visualized with a Leitz Laborlux S Fluorescence Microscope under UV light. Images were acquired with a Zeiss AxioCam digital camera. Pectic polysaccharides were stained according to the same procedure, but in this case, Calcofluor was replaced by 2-3 drops of $1 \%(\mathrm{w} / \mathrm{v})$ Toluidine Blue and the slides were observed under light microscopy. Cells were measured using the Carl Zeiss Vision AxioVision Viewer 4.

\subsection{Immunolocalization with monoclonal antibodies}

Callus were gently desegregated and equilibrated in 5\% dry milk/PBS for 30 min at RT and then incubated overnight at $4{ }^{\circ} \mathrm{C}$ with a 10-fold dilution of 2F4 or PAM1 antibodies (Liners et al., 1989; Willats et al., 1999) diluted in 5\% w/v non-fat dry milk/PBS. After extensive washing with PBS, a 30 -fold dilution of the secondary antibody (anti-mouse IgG and anti-rat IgG (Sigma), respectively) was applied to the sections and left to incubate for $60 \mathrm{~min}$ in the dark. For negative controls the primary antibodies were omitted. The slides were then washed with PBS and briefly incubated with $1 \%(\mathrm{w} / \mathrm{v})$ Calcofluor White in distiled water, rinsed and mounted on a microscope slide. Sections were observed with a Leitz Laborlux S Fluorescence Microscope and images were acquired using a Zeiss AxioCam digital camera. The Images were superimposed and analyzed using the ImageJ 1.48 package (http://imagej.nih.gov/ij/ ). The average number of blue pixels (Calcofluor) and green pixels (PAM1 and 2F4) was quantified.

\section{Gene expression analyzes}

\subsection{Database mining and sequence retrieval of $\mathrm{V}$. vinifera CW-related genes}

Sequences from members of the CesA, EXPA, XTH, EGase from here on referred as GH9 (http://www.cazy.org), PME and PMEI families were retrieved by multiple database searches for $V$. vinifera and three other model species with sequenced genomes, namely tale cress (A. thaliana), rice (Oryza sativa) and poplar (Populus trichocarpa). The NCBI (http://www.ncbi.nlm.nih. gov/) and Genoscope 12X (http://www.genoscope.cns.fr/spip/) databases were used for $V$. vinifera gene searches while TAIR (http:// www.arabidopsis.org/index.jsp), OryGenesDG (http://orygenesdb. cirad.fr/cgi-bin/gbrowse/odb_japonica/?name=Os_1:1..10000) and Phytozome (http://www.phytozome.net/poplar) were mined for Arabidopsis, Oryza and Populus, respectively. In each case, after identification of the amino acid sequence, the same database was mined for each hit to retrieve the full-length cDNA sequence of the predicted corresponding gene. $V$. vinifera sequences were named according to their similarity with Arabidopsis orthologous. After prediction (SignalP 4.0; Petersen et al., 2011) and removal of signal peptides from the amino acid sequences, alignments were performed using MUSCLE software (Edgar, 2004a,b) and curated by Gblocks software (Talavera and Castresana, 2007). The dendrograms were constructed using PhyML (Guindon et al., 2010), and viewed using TreeDyn software (Chevenet et al., 2006). Putative biological activity was inferred from amino acid sequences using InterProScan 5 (http://www.ebi.ac.uk/Tools/pfa/iprscan5/; Quevillon et al., 2005. Tertiary structure-models were predicted using the alignment-based modeling tools SWISS-MODEL (http:// swissmodel.expasy.org/; Arnold et al., 2006) and SwisspdbViewer DeepView 4.0 (http://www.expasy.org/spdbv/; Guex and Peitsch, 1997).

\subsection{RNA extraction and cDNA synthesis}

Total RNA was extracted from $V$. vinifera callus using the method described by Reid et al. (2006). RNA samples were further treated with RNase-free DNase I (Qiagen) according to the manufacturer protocol. Quantification was carried out in a Synergy HT Multiplate Reader, with Gene5 software, using a Take ${ }^{\mathrm{TM}}$ Multi-Volume Plate (Bio-Tek Instruments Inc., Winooski, USA). For reverse transcription, the RevertAid reverse transcriptase priming with oligo-d(T) kit was used (Thermo Scientific) according to the manufacturer's recommendations.

\subsection{Quantification of gene expression by quantitative real-time $P C R(R T-q P C R)$}

For each $V$. vinifera cDNA sequence retrieved, a set of specific primers were designed (Table $\mathrm{S} 1$ ) and used to amplify callus grapevine cDNA resulting from the transcription of $2 \mu \mathrm{g}$ of total RNA, using conventional PCR and gel agarose electrophoresis. When amplification was observed, confirming the expression in callus tissues, the transcripts were quantified by real-time PCR (RTqPCR), performed in $20 \mu \mathrm{L}$ reaction volumes composed of cDNA derived from $2 \mu \mathrm{g}$ RNA, $0.5 \mu \mathrm{M}$ gene-specific primers (Table S1) in SsoFast ${ }^{\mathrm{TM}}$ EvaGreen ${ }^{\circledR}$ Supermixes (Bio-Rad, Hercules, CA) using a iQ5 Real-Time Thermal Cycler (BioRad, Hercules, CA). Reactions conditions for cycling were: $9^{\circ} \mathrm{C}$ for $3 \mathrm{~min}$ followed by 40 cycles of $9^{\circ} \mathrm{C}$ for $10 \mathrm{~s}, 61^{\circ} \mathrm{C}$ for $2 \mathrm{~s}$ and $2{ }^{\circ} \mathrm{C}$ for $30 \mathrm{~s}$. Melting curves were generated in each case to confirm the amplification of single products and absence of primer dimerization. Each analysis was performed in triplicate reactions of three biologic replicates. The corresponding quantification cycles $\left(C_{q}\right)$ were determined by the iQ5 optical system software (Bio-Rad, Hercules, CA) and exported to a MS Excel spreadsheet (Microsoft Inc., CA) for further analysis. $C_{q}$ values of each gene of interest were normalized with respect to actin (Act) and translation initiation factor eIF-3 subunit 4 (TIF) $C_{\mathrm{q}}$ s (Coito et al., 2012). Relative gene expression values in the absence of a given nutrient $(-\mathrm{N},-\mathrm{P},-\mathrm{S})$ are presented as $\log _{2}$ fold-change values in relation with the control conditions $(C)$. Heat Map was performed with Pearson correlations using the MeV software (Saeed et al., 2003).

\section{Evaluation of callus salt extract potential to induce $\mathrm{CW}$ extensibility}

\subsection{Preparation of salt extracts}

Samples of $20 \mathrm{~g}$ (FW) V. vinifera callus tissues growing under each experimental condition were cut into small pieces and washed with $20 \mathrm{mM} \mathrm{NaOAc} \mathrm{pH} 4.5$ buffer. The washed callus samples were filtered by vacuum and the flowthroughs were discarded. Twenty milliliters of a $20 \mathrm{mM} \mathrm{NaOAc} ; 1 \mathrm{M} \mathrm{KCl} \mathrm{pH} 4.5$ solution were then added to the callus and the mixtures were incubated for $30 \mathrm{~min}$ at $4{ }^{\circ} \mathrm{C}$, filtered and each solution was concentrated to $1 \mathrm{ml}$ using Amicon Ultra Ultracell $3 \mathrm{~K}$ columns (Millipore) as per the manufacturer's recommendations and desalinized with PD-10 desalting columns (cut-off 5 kDA) (GE, Fairfield, USA). Protein in each callusderived extract was quantified using the Bradford (1976) method 
with BSA as standard. The same extracts were evaluated for ability to induce extensible deformation in cucumber hypocotyl sections, taken as model for dicot CW specimens, and tested for $\beta$-1,4-endoglucanase activity.

\subsection{Extensibility assays}

Cucumber seeds were sown at $25^{\circ} \mathrm{C}$, in the dark and germinated hypocotyl apical zones $(3 \mathrm{~cm})$ were cut and stored at $-20^{\circ} \mathrm{C}$. Prior to the analyzes, the hypocotyls cuticles were abraded using carborundum powder and samples were boiled for $1 \mathrm{~s}$. to inactivate endogenous enzymes. The hypocotyls were then assayed clapped to tension grips in a TA-XT Texture Analyzer (Stable Micro Systems Ltd., UK), using a custom made clamping reservoir filled with $50 \mathrm{mM}$ NaOAc pH 4.5 buffer. A $20 \mathrm{~g}$ load tensile force was applied with a $1.5 \mathrm{~mm}$ test length between clamps and, after a $20 \mathrm{~min}$ period of extension for equilibration, the buffer was replaced by each saline extract solution being tested and assayed for additional $15 \mathrm{~min}$. The force was then removed during $10 \mathrm{~min}$ and reapplied for additional $20 \mathrm{~min}$, to allow calculation of Total, Plastic and Elastic extensibilities (Cosgrove, 1993). Total extensibility was calculated as the maximum hypocotyl length at constant load. Plastic extensibility was calculated as the minimum value reached after force removal. Elastic extensibility is the difference between the total and plastic extensibility (Richmond et al., 1980). Each experiment was performed using at least 6 independent samples for each treatment.

\section{3. $\beta$-1,4-Endo-glucanase activity}

Endo-acting glycosyl hydrolase activity was measured by the change in viscosity of a carboxymethylcellulose (CMC) (medium viscosity, Sigma) solution (Durbin and Lewis, 1988). One hundred microlitre of each salt extract, at a concentration of $3 \mu \mathrm{g} \mu \mathrm{l}^{-1}$, were added to $350 \mathrm{ml}$ of a $1.5 \%(\mathrm{w} / \mathrm{v}) \mathrm{CMC}$ solution in $20 \mathrm{mM}$ phosphate buffer $\mathrm{pH} 6.0$, incubated for $6 \mathrm{~h}$ at $37^{\circ} \mathrm{C}$. Viscosity was determined by measuring the time taken for the movement of the mixture through the 0 and the $0.05 \mathrm{ml}$ marks of a $0.1 \mathrm{ml}$ glass pipette fixed in a vertical position using a stopwatch. Readings were taken at time $0 \mathrm{~h}, 2 \mathrm{~h}$ and $6 \mathrm{~h}$ in triplicates. Activity is reported as the decrease in viscosity (\%) with respect to time zero.

\subsection{Statistical analysis}

All data is presented as mean values \pm standard deviation (SD) of an appropriate number of replicates in each assay. The results were statistically evaluated by variance analysis (ANOVA) and post hoc Bonferroni test with a $p<0.05$ to compare the significance of each treatment effect. The SigmaPlot (Systat Software Inc.) statistical package was used.

\section{Results}

\subsection{Callus growth in $-N,-P$ and $-S$ and full $M S$ medium}

The effect of the imposed individual mineral stresses on the Vitis callus was assessed by measuring the callus growth along time. After withdrawing of nutrients, the relative growth of the callus was significantly affected in the three cycles when compared to the control (Fig. S1). After the first cycle, $-\mathrm{N}$ callus cells were the most affected; at the end of the second cycle the three mineral stresses severely affected callus growth impairing their viability thereafter. So, six weeks old callus were selected for subsequent analyzes.

Supplementry material related to this article found, in the online version, at http://dx.doi.org/10.1016/j.jplph.2015.10.007.
Table 1

Measured length and width of $V$. vinifera callus cells after six weeks growth in complete nutrient medium (control), and in the absence of nitrogen $(-\mathrm{N})$, phosphorus $(-\mathrm{P})$ and sulfur $(-\mathrm{S})$. Values are the mean \pm SD of 20 random cells. Different letters in each row indicate significant differences at $p<0.05$.

\begin{tabular}{lcccc}
\hline & Control & $-\mathrm{N}$ & $-\mathrm{P}$ & $-\mathrm{S}$ \\
\hline Length $(\mu \mathrm{m})$ & $121.0^{\mathrm{a}} \pm 12.1$ & $228.7^{\mathrm{b}} \pm 38.9$ & $147.9^{\mathrm{c}} \pm 19.1$ & $130.5^{\mathrm{a}} \pm 13.3$ \\
Width $(\mu \mathrm{m})$ & $48.6^{\mathrm{a}} \pm 3.5$ & $47.2^{\mathrm{a}} \pm 2.7$ & $49.4^{\mathrm{b}} \pm 2.0$ & $48.1^{\mathrm{a}} \pm 3.2$ \\
\hline
\end{tabular}

\subsection{Cell morphology in response to mineral deficiencies}

A first indication of the effect of stress imposition in the callus tissues using the biological system used was gained through measurement of cell anatomical parameters. Except for sulfur, the absence of individual minerals produced changes in the morphology of $V$. vinifera callus cells (Table 1 ). Noticeably, the deprivation of each mineral effected different alterations to the cell morphology. Under nitrogen starvation the cells were longer but had a similar width, when compared with the control. On the other hand, under phosphorus depletion the cells were longer and wider than the control, although still shorter than under $-\mathrm{N}$ conditions (Table 1).

\subsection{In situ localization of callus CW polymers and epitopes}

Calcofluor White was used to detect CW matrix polysaccharide as it readily binds to cellulose. The absence of minerals in the medium resulted, in all callus tissues, in a reduced intensity of Calcofluor labeling. This reduction was more pronounced in samples produced under nitrogen starvation (Fig. 1; Table S2). Toluidine Blue binds to carboxylated polysaccharides such as pectins, producing a reddish purple staining. As observed in Fig. 1, in the absence of nitrogen a more intense staining occurs. Immunolocalization with monoclonal antibodies targeted to specific CW epitopes is a useful tool to analyze in vivo detailed localization of CW components and was employed to ascribe putative modifications in the CW composition in response to the imposed stresses, targeting differences in methyl esterification patterns. The combined use of CW-epitope antibodies and histological dyes enabled us to gain more detailed information regarding differences in the pectic composition. The results show that, under $-\mathrm{N}$ and $-\mathrm{S}$ conditions, an increase in $2 \mathrm{~F} 4$ labeling, an antibody that recognises dimeric association of pectic chains through calcium ions, is observed in the whole cell, being more prominent in the middle lamella (Fig. 1; arrows). On the other hand, PAM1, which recognizes epitopes of long un-esterified blocks of GalA residues, did not bind to the boundaries of the cell in $-\mathrm{N}$ and $-\mathrm{S}$ callus tissues, while it was clearly noticeable in these specific regions in cells of callus growing under full nutrients and faintly under -P conditions (Fig. 1; arrow; Table S2).

\section{Changes in gene expression of $\mathrm{CW}$-related families}

\subsection{In silico analyzes}

The initial approach was to evaluate the relationship of CW synthesis and modification candidate gene families between $V$. vinifera and annotated genes in other flowering species. In silico analysis showed that, in general, the $V$. vinifera genome has a similar number of members to Arabidopsis, Oryza and Populus for CW-related gene families that act on cellulose-hemicellulose complexes (Table 2). $V$. vinifera and $O$. sativa showed a significantly lower number of PME members identified in the databases than the other two species used for comparison. On the other hand, the number of PMEIs varied according to each individual species, being lower in A. thaliana ( 6 members) and higher in $O$. sativa (13 members). It should be however noted that database mining did not differentiate true PMEI 


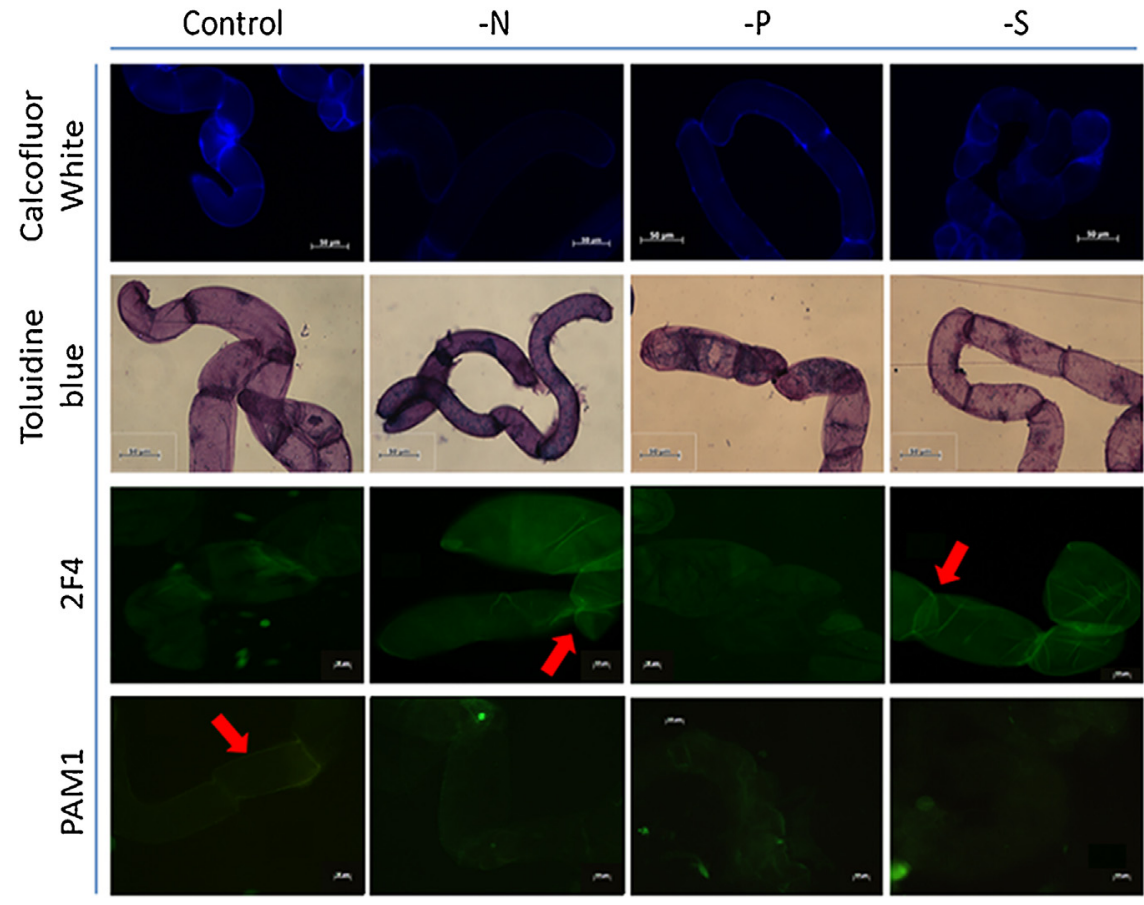

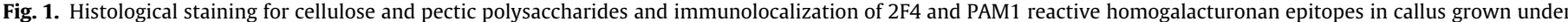

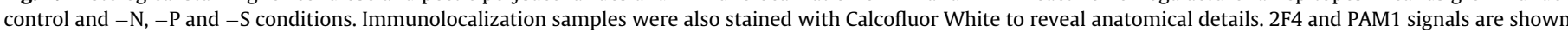

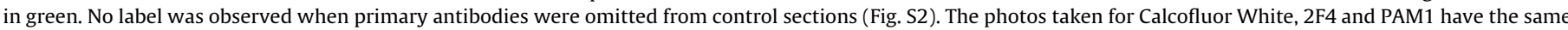
exposition time for all treatments. Bar scale for histological observations represents $50 \mu \mathrm{m}$ (and) and $10 \mu \mathrm{m}$ for immunolocalization of $2 \mathrm{~F} 4$ and PAM1.

Table 2

Number of genes related to primary CW biosynthesis and modification retrieved in silico from the higher plant sequenced species Vitis vinifera, Oryza sativa, Populus trichocarpa and Arabidopsis thaliana genomes.

\begin{tabular}{lllll}
\hline & $\begin{array}{l}\text { Vitis } \\
\text { vinifera }\end{array}$ & $\begin{array}{l}\text { Arabidopsis } \\
\text { thaliana }\end{array}$ & $\begin{array}{l}\text { Oryza } \\
\text { sativa }\end{array}$ & $\begin{array}{l}\text { Populus } \\
\text { trichocarpa }\end{array}$ \\
\hline CesA & 10 & 10 & 10 & 18 \\
Expansin superfamily & 30 & 36 & 56 & 36 \\
XTH & 33 & 33 & 29 & 24 \\
GH9 & 21 & 25 & 24 & 31 \\
PME & 36 & 66 & 37 & 84 \\
PMEI & 11 & 6 & 13 & 10 \\
\hline
\end{tabular}

from invertase inhibitors. A higher number of EXPAs (53 members) was retrieved from the $O$. sativa genome.

The dendrograms built with amino acid sequences, reveals that, in general, $V$. vinifera $\mathrm{CW}$-related sequences cluster with orthologs from monocot, dicot and woody model species in most families (Figs. S3-S5). Noticeably, in the XTH family, some clusters are enriched with $V$. vinifera sequences.

Supplementry material related to this article found, in the online version, at http://dx.doi.org/10.1016/j.jplph.2015.10.007.

Since XTH genes encode proteins that can have two distinct catalytic activities, sequence alignments and structural in silico analysis were performed to distinguish putative xyloglucan endotransglucosylases (XET) from xyloglucan endohydrolases (XEH) (Fig. S6). The XTH identity was confirmed by the presence in all $V$. vinifera sequences of the conserved catalytic motif $(\mathrm{W} / \mathrm{R})-(\mathrm{D} / \mathrm{N})-$ $\mathrm{E}-(\mathrm{I} / \mathrm{L} / \mathrm{F} / \mathrm{V})-\mathrm{D}-(\mathrm{F} / \mathrm{I} / \mathrm{L} / \mathrm{M})-\mathrm{E}-(\mathrm{F} / \mathrm{L})-(\mathrm{L} / \mathrm{M})-\mathrm{G}$, as previously described by Eklöf and Brumer, (2010) and XET or XEH putative activities were assigned based on the presence/absence of two insertions, $(\mathrm{Y} / \mathrm{N})-\mathrm{P}$ G and R-(I/L)-I-G-R (Fig. S7) in the amino acid sequence (Eklöf and Brumer, 2010). Based on these structural differences, two isoforms, VviXTH31 (XP_002275862) and VviXTH32 (XP_002269285), were identified. Despite the insertions, the structural similarity between XET and XEH was found to be very high, as indicated by the super- imposition of their backbones (Fig. S6). The main difference occurs between species, especially in the C-terminus in which an $\alpha$-helix is observed both in Tropaeolum majus and Arabidopsis but is absent in $V$. vinifera.

Supplementry material related to this article found, in the online version, at http://dx.doi.org/10.1016/j.jplph.2015.10.007.

Likewise, PMEIs share structural properties with other invertase inhibitors and its classification was proposed to be possible based on the conformation features of an extension that precedes a fourhelix bundle core (Scognamiglio et al., 2003). We noticed a high similarity between $V$. vinifera and Arabidopsis PMEI, which showed similar extension (Fig. S8).

Supplementry material related to this article found, in the online version, at http://dx.doi.org/10.1016/j.jplph.2015.10.007.

\subsection{Changes in expression of key genes involved in the} biosynthesis and modification of CW under mineral stress

One way of tackling the pathways of a given physiological event is to understand the transcription of related genes. Thus, isoforms of several gene families (Table S1) were chosen based on their putative role in the synthesis and modification of CW after nutrient starvation. Fifty out of the 131 genes investigated (38.2\%) expressed in the callus tissue and their expression level was quantified by RT-qPCR as shown in Figs. 3 and 4 in Table S3 with more detail.

Supplementry material related to this article found, in the online version, at http://dx.doi.org/10.1016/j.jplph.2015.10.007.

Although a similar number of genes had been up- and downregulated in response to individual mineral stress imposition, the majority of them were downregulated in all treatments (Fig. 2). Seven showed up-regulation in all stress conditions (VviCesA2, VviEXP8, VviXTH8, VviXTH10, VviPMEI2, VviPMEI3 and VviPMEI4) (Fig. 2a), while 16 were down-regulated in all treatments (VviCesA4, VviXTH32, VviGH9A1, VviGH9C2, VviXTH2, VviEXP5, VviEXP3, VviEXP11, VviXTH15, VviPME1.17, VviPME1.18, VviPME1.19, VviPME2.4, 

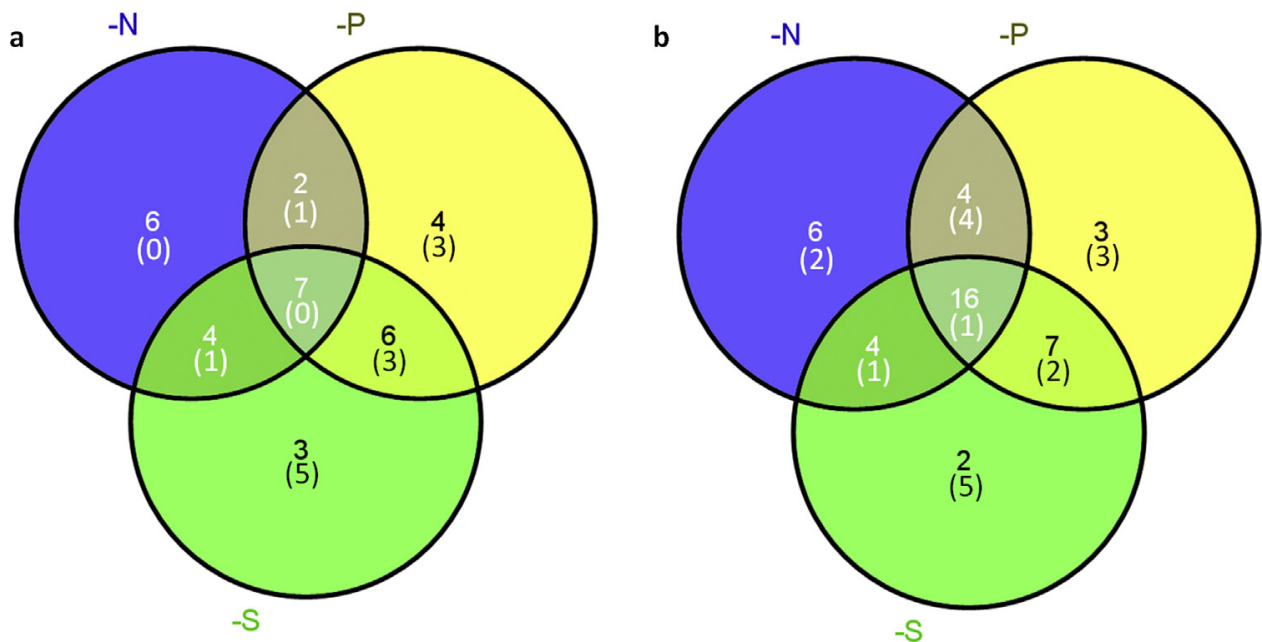

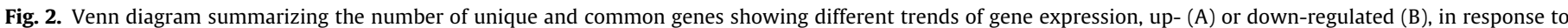

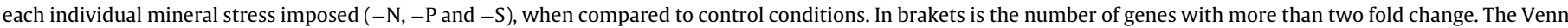
diagram was drawn using the Venny Tool (Oliveros, 2007).

VviPME2.7, VviPME2.14, VviPME2.20) (Fig. 2b). The number of genes with detected altered expression was always higher in $-\mathrm{N}$, followed by $-\mathrm{P}$ and lower in $-\mathrm{S}$ callus samples which, as showed by hierarchical clustering (Fig. 3) indicates that samples from $-\mathrm{N}$ callus tissues have more uncorrelated transcription patterns than the samples obtained under the other two conditions.

Concerning the genes studied that can be putatively associated with cellulose biosynthesis, the results disclosed the up-regulation of one CesA gene in response to nitrogen (VviCesA3) and phosphorus (VviCesA8) deficiencies in the growing medium, and three members in response to sulfur (VviCesA1-3) deprivation, whereas the transcription of VviCesA6 was 3-fold repressed under -S conditions. GH9A, which are orthologous to KORRIGAN genes, showed not to be differentially expressed in response to the mineral stress imposition but a severe reduction of 4.45 and 5.25 fold-change in the class C, VviGH9C2, transcript amounts was observed in samples growing under nitrogen and sulfur deficiency, respectively (Fig. 3).

EXPA gene expression was similarly regulated in response to nitrogen and phosphorus deficiencies, as illustrated by the downregulation, in both cases, of two isoforms, VviEXP6 and VviEXP11 (Table S3). Transcription impairment of those members was particularly severe in -P conditions (Fig. 3). Noticeably, VviEXP6 transcripts showed a 2 -fold increase under $-\mathrm{S}$ starvation and the absence of this mineral in the growing medium repressed the transcription of three other EXPA family members (VviEXPA5, VviEXPA19 and VviEXPA20).

Out of the $10 \mathrm{XTH}$ members expressing in callus tissue, two (VviXTH31 and VviXTH32) were predicted by sequence analyzes as candidates to have hydrolase activity (Fig. S7). The quantified gene expression of VviXTH32 was significantly compromised in response to all stress conditions (Fig. 3). Moreover, VviXTH31 was also strongly repressed under nitrogen deficiency (Table S3). The remaining XTHs were differently regulated according to the specific experimental condition. Under nitrogen deficiency only VviXTH14 was differently expressed, showing a 3 . fold down-regulation. Under $-\mathrm{P}$, which was the condition that affected more XTHs, this member was also repressed, together with VviXTH2 and VviXTH15 while VviXTH4 showed a clear up regulation. On the contrary, under -S conditions no significant XTH down-regulation was detected, with two genes (VviXTH4 and VviXTH8) up-regulated (Table S3).

More PME genes were down-regulated under mineral starvation than up-regulated. The latter situation was observed for the same two members, VviPME1.4 and VviPME1.1, in both -P and, to a higher extent, $-S$ conditions. About $1 / 3$ of the PME genes quantified were down-regulated in each experimental condition. Some displayed the same pattern in response to more than one stress, namely VviPME1.19 and VviPME2.14 under -P and -S, and VviPME2.20 under $-\mathrm{N}$ and $-\mathrm{P}$. VviPME1.1 was down-regulated in response to all stresses. Highlighted is the response of VviPME1.4 which was severely impaired under nitrogen (5-fold down regulation) and strongly induced under sulfur starvation (6-fold up-regulation) (Fig. 3). Interestingly, under mineral depletion, PMEI gene expression showed to be generally up-regulated, although a different member was affected according to each individual mineral stress under $-\mathrm{N}$ and $-\mathrm{S}$ conditions and phosphorus starvation significantly impacted three out of the four PMEIs expressing in $V$. vinifera callus tissues. Collectively PME down-regulation results suggest a reduction in enzymatic de-esterification potential under imposed mineral stress.

\subsection{Loosening activity from callus extracts}

The occurrence of different amounts and relative proportions of the protein mixture that acts on the CW to alter its structural properties can be addressed by measuring the changes in extension that they able to induce. Salt extracts from the four experimental samples were added to cucumber hypocotyls, used as model dicot CW specimens, in an extensometer assay and a significant increase in the total deformation was observed when the $-\mathrm{N}$ and $-\mathrm{P}$ extracts were used (Fig. 4). The effect was more evident in extracts isolated from $-\mathrm{N}$ callus even though the total quantity of extractable proteins had been lower than in the other conditions (Fig. 4. Inset $\mathrm{KCl}$ extracts). The higher total deformation observed is the direct result of an increase of the plastic deformation since the elastic deformation was not significantly affected by any of the mineral stresses. Endoglucanase activity was estimated through a viscosity test where the higher the decrease in CMC substrate viscosity after incubation with acting enzyme solutions, the higher the enzymatic activity. After two hours incubation, the extracts prepared from $-\mathrm{N}$ callus showed significantly lower activity than all the other treatments, while in those obtained from $-\mathrm{S}$ and $-\mathrm{P}$ higher activities were measured as compared to the control (Fig. 5).

\section{Discussion}

Taking advantage of the optimized experimental callus model system, insights into the regulation underlying the effects of limiting nutrient supply to cell development through CW dynamics were gained. A previous work based on FT-IR spectroscopy and bio- 


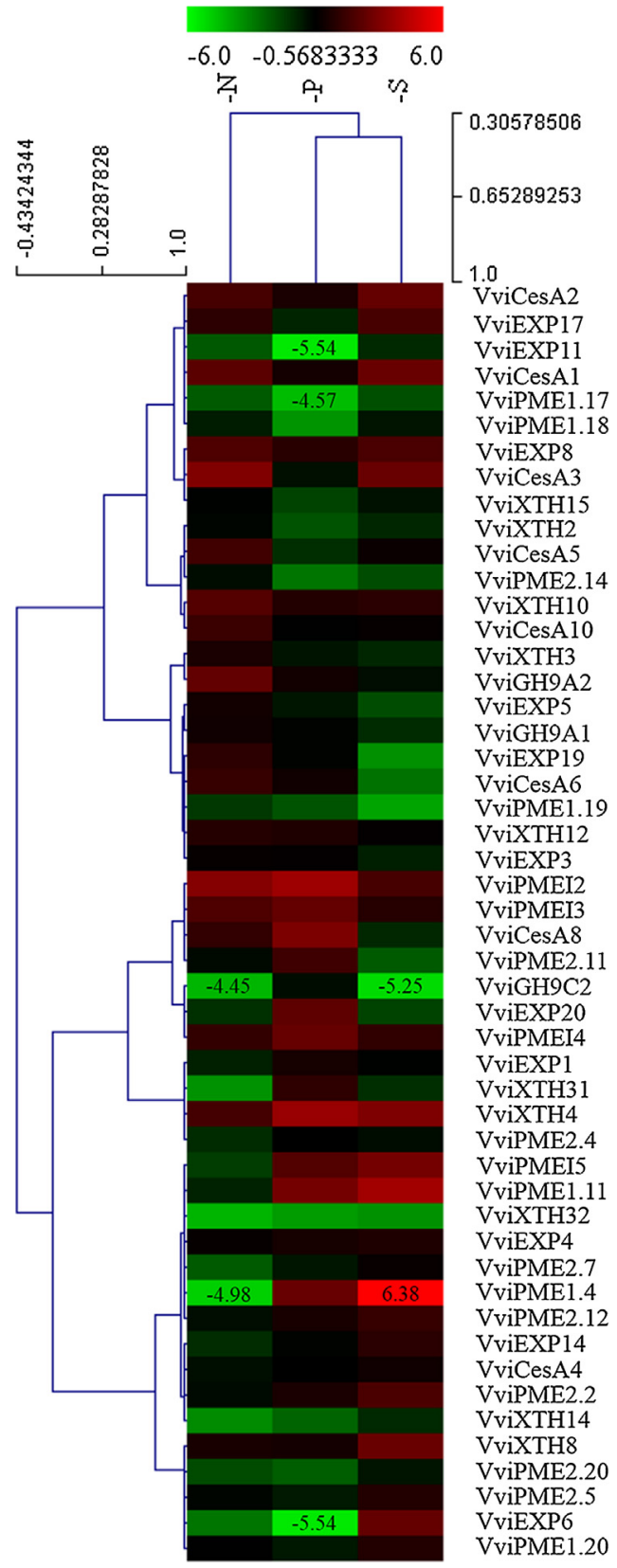

Fig. 3. Differentially expressed genes transcribed in callus under mineral stress with respect to callus grown under complete medium. Hierarchical clustering was performed on $50 \mathrm{CW}$-modifying-encoding genes from candidate families showing expression in callus tissues. Gene dendrogram (left) and condition dendrogram (top) were obtained using Pearson's uncentered distance metric calculated from all $\log _{2}$ transcription ratios (mineral stress/control). Color scale from green to red indicates $\log _{2}$ transcription ratios from 6-fold under transcription to 6-fold over transcription). The exact value of relative expression is given when a striking fold change of 4 was observed, although in this paper we discuss differences in gene expression when the fold change at least doubles. Each gene is identified by the code provided in Supplementary material 1.

chemical quantification of CW components reports changes in the amount or rearrangements of cellulose and matrix linked glycans, in the levels of pectin methyl-esterification and in the strength the polysaccharides associate into the $\mathrm{CW}$ as the main effects induced by N, P and S mineral deprivation (Fernandes et al., 2013).

Confirming biochemical changes observed (Fernandes et al., 2013), under mineral stress a reduction in cellulose and an increase in pectin contents were perceived via Calcofluor and toluidine blue labelling, respectively. Similarly, higher labelling by the antibody

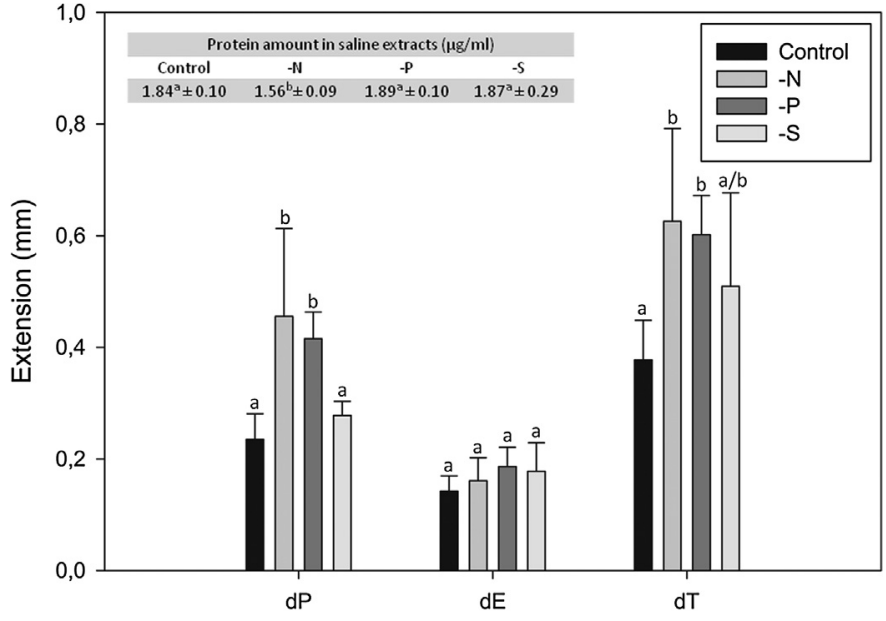

Fig. 4. Plastic (dP), Elastic (dE) and Total (dT) deformation of cucumber hypocotyls when salt extracts from callus grown under nitrogen $(-\mathrm{N})$, phosphorus $(-\mathrm{P})$, sulfur $(-S)$ depletion and control $(C)$ were applied. Inner table represents the protein quantification for the salt extracts from $-\mathrm{N},-\mathrm{P},-\mathrm{S}$ and control $\pm \mathrm{SD}$ of 6 measurements. The same amount of soluble protein, in each treatment, was used in all tests. Different letters indicate significant differences at $p<0.05$.

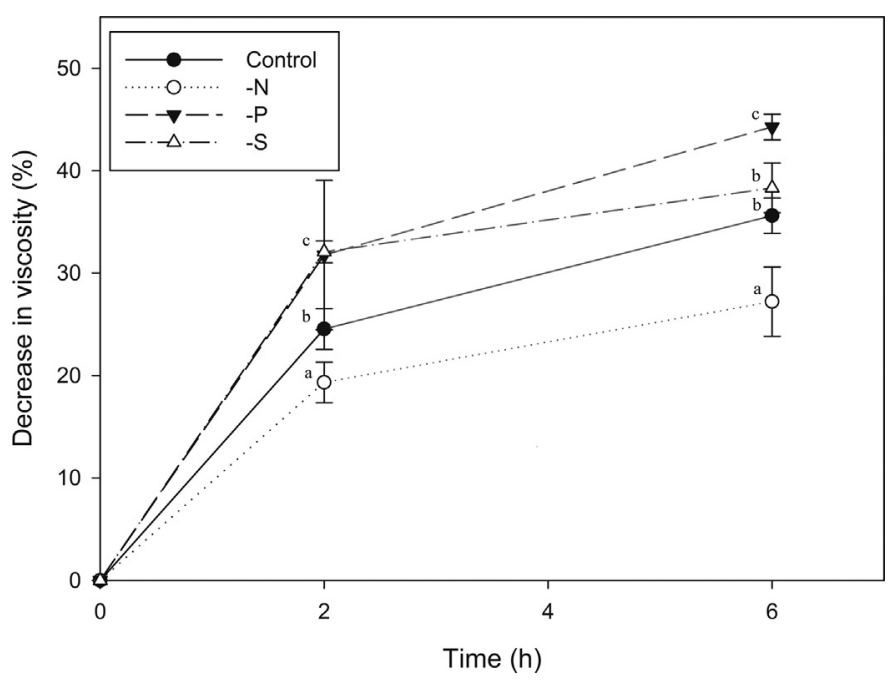

Fig. 5. $\beta-1,4$-Endo-glucanase activity of salt extracts from callus grown under nitrogen $(-\mathrm{N})$, phosphorus $(-\mathrm{P})$, sulfur $(-\mathrm{S})$ depletion and control $(\mathrm{C})$. Activity is given as the decrease in viscosity (\%) with respect to time zero. The same amount of soluble protein, in each treatment, was used in all tests. Different letters indicate significant differences at $p<0.05, n=9$.

identifying dimeric associations of pectic chains through calcium ions, 2F4, was detected in $-\mathrm{N}$ callus, supporting the evidence of a lower degree of methyl-esterification, and the promotion of the conditions favorable to the formation of calcium bridges (Pelloux et al., 2007).

CW-biosynthesis and modification associated genes are present in large multigenic families with related overlapping functions which may lead to compensatory mechanisms for the transcription changes of most of these genes (Giovannoni, 2004). Making use of the sequenced $V$. vinifera genome availability (Jaillon et al., 2007; Velasco et al., 2007) list, a comprehensive in silico analysis was conducted to, in a first step, compare the size of the gene families with other plant model species. Then, the transcription pattern of genes encoding CW synthase, hydrolase, trans-glycosylase, expansin and esterase enzymes which, based on their known modes of action and combined activity may result in the observed changes, were examined. This approach was complemented with the evaluation of 
salt extracts loosening-promoting activity on dicot CW specimens (Figs. 4 and 5).

Most of the $V$. vinifera $C W$-related gene families include a similar number of members than $A$. thaliana, $O$. sativa and $P$. trichocarpa. Moreover, the dendrogram analysis of $V$. vinifera $C W$-related amino acid sequences, showed clustering with orthologues from those in model species (Figs. S3-S5), as previously observed by Baumann et al. (2007), suggesting a conservation of CW biosynthesis and modification mechanisms throughout angiosperm evolution.

Gene expression of key candidate genes above a $\log _{2} \pm 2$-fold change relative to the control showed that responsive members were detected in all families (Fig. 2 and Table S3). Despite the impact of nitrogen starvation, leading to more dramatic developmental and morphological modifications in callus tissues (Fernandes et al., 2013; Fig. S1), a lower number of genes with significant expression alteration, was observed. (Fig. 3 and Table S3). Lower levels of cellulose were detected under $-\mathrm{N}$ and $-\mathrm{P}$ (Fernandes et al., 2013; Fig. 2), which lead us to investigate the gene expression of families associated with cellulose biosynthesis. CesA are present in multigenic families with at least 10 members in A. thaliana, 10 in $O$. sativa (Richmond and Somerville, 2000), and at least 18 in P. trichocarpa (Suzuki et al., 2006). Except for VviCesA6 under -S conditions, all other significantly affected genes showed an increased (ca. $2-3 \log _{2}$ fold-change) transcript accumulation, not explaining the reduction in the observed cellulose content. In Arabidopsis, three distinct CesA proteins are required to produce cellulose (Desprez et al., 2007). If VviCesA6 is the counterpart of AtCesA6, it can be assumed that the callus primary $\mathrm{CW}$ in our experimental system may have been affected in similar way to the irregular xylem (irx) mutant lines which harbor lesions in AtCesAs 4, 7, and 8 (Taylor et al., 2003). Accepting the hypothesis of non-redundancy, in the lack of one of the proteins the assemblage of the complex is impaired without formation of the cellulose microfiber (Desprez et al., 2007). Strikingly, VviCesA down-regulation was observed only under -S conditions, which is the only tested mineral that does not impact a reduction in cellulose content (Fernandes et al., 2013).

Nevertheless, CesA activity is not sufficient to produce cellulose, requiring the combined action with members from other families. Among those, the sub-classes A and C of the GH9 family is also known to interact in cellulose biosynthesis. Regarding class A, a mutant (KORRIGAN) impaired in this gene expression showed a dwarf phenotype and changes in the cellulose-XyG network, demonstrating that these gene members are essential for a correct cellulose formation (Nicol et al., 1998). V. vinifera callus tissue growing under mineral stress did not show significant modifications in the expression of these gene members. On the other hand, class C GH9 harbors a cellulose binding module (CBM) attached to the C-terminus of the catalytic domain (Urbanowicz et al., 2007b), and its role in cellulose biochemistry was recently demonstrated in $P$. trichocarpa. In this species, a specific member, PtGH9C2, showed to be involved in regulating the degree of cellulose crystallinity (Glass et al., 2015). As proposed by Fujita et al. (2011) this property regulates the rate of expansion of the primary $\mathrm{CW}$ by restricting the number of cross-links with hemicelluloses (Lai-Kee-Him et al., 2002). PtGH9C2 may play a role in cessation of primary growth, thereby resulting in impaired or enhanced growth of poplar lines overexpressing or RNAi suppressed, respectively (Glass et al., 2015). Under mineral stress the only GH9C that expressed in callus tissues, VviGH9C2, was severely down-regulated under $-\mathrm{N}$ and, surprisingly, under -S conditions, showing an invariant expression pattern under -P (Figs. 1 and 3 and Table S3). The observed reduction in endoglucanase activity under $-\mathrm{N}$ (Fig. 5) could cause the inhibition of microfibril crystallization and consequent increase celluloseXyG cross-linking to reinforce the wall (Fujita et al., 2011).

Under -P and -S specific XTH and PME family members were up-regulated, while others were repressed. This observation can be related to the opposite effects in CW modifications that, as discussed, particular members of both families can exert (Osato et al., 2006). Regarding XTHs, the enzymes coded by this gene family can hold distinct activities, xyloglucan endotransglucosylase (XET), xyloglucan endohydrolase (XEH) or both, often to produce paradoxal effects on the CW (Eklöf and Brumer, 2010). Hence the assignment of each $V$. vinifera XTH to a putative activity was conducted based on sequence analyzes (Eklöf and Brumer, 2010). As expected, and in accordance with Johansson et al. (2004) in Populus, key active-sites revealed subtle differences restricted to two loops outside the substrate-binding cleft, attributed to two insertions in XTH enzymes proposed to display XEH activity (Eklöf and Brumer, 2010). Two V. vinifera XTH proteins displayed an insertion of those motifs, making them strong candidates as XEHs (Fig. S7). The number of $V$. vinifera of XTH-XEH members is similar to the one in the A. thaliana genome (Baumann et al., 2007) and, in the present study, these genes were repressed under all mineral stresses, often at high levels. Recent studies reported by Kaewthai et al. (2013) demonstrate that these enzymes have no significant effect on growth patterns or developmental phenotypes, which may suggest their action as key enzymes in a XyG-recycling pathway where an excess of non-reducing ends leads to a reinforced XyG network (Sampedro et al., 2010, 2012). On the other hand, XTH genes may function redundantly (Matsui et al., 2005), with the repression of one member compensated by the up-transcription of others.

PME genes also belong to a multigene family (Markovic and Janecek, 2004). Some members carry an N-terminal PRO region extension, which precedes a conserved domain similar to the PMEI domain (Jolie et al., 2010). Depending on the absence or presence of this PRO region, PMEs are classified into two subfamilies: type II/group 1 and type I/group 2 respectively (Micheli, 2001). After the integration into the CW, PMEs can randomly or linearly de-esterify the HG chain (Markovic and Kohn, 1984). Random PME de-esterification activates the polygalacturonase activity promoting the CW loosening while linear PME de-esterification can promote $\mathrm{Ca}^{2+}$-linked gel structures and stiffen the CW (Micheli, 2001). It is referred that plant PMEs with an acidic pI act in a nonblock-wise fashion, while plant basic pI PMEs, which represents most isoforms, act in a block-wise fashion (Bosch and Hepler, 2005) making these families strong candidates to act in compensatory mechanisms within the same function. Hence, the lower global degree (Fernandes et al., 2013) and pattern (Fig. 1) of methylesterification observed under some mineral starvation conditions cannot be directly explained by the PME gene expression levels. In fact most PME genes were down-regulated and all PMEI genes were up-regulated with the exception of the basic PME1.4 and PME1.11 under $-\mathrm{P}$ and $-\mathrm{S}$. An equivalent balance between PME and PMEI controlling the rate of de-esterification, was observed in Arabidopsis roots (Wilson et al., 2015). From these findings we hypothesize that under mineral stresses the basic PMEs produce long linear stretches of unesterified HG chains promoting the formation of $\mathrm{Ca}^{2+}$-linked gel structures and, in this way, stiffening the CW. As a whole, the results of gene expression changes in response to the individual mineral stresses are in accordance with previous evidences that the response and eventual adaptation are specific to each stress.

After incubation of protein salt extracts with heat inactivated cucumber hypocotyl used as dicot CW specimens under conditions that promote extensibility, increases in the plastic deformations were observed under $-\mathrm{N}$ and $-\mathrm{P}$ callus (Fig. 4). Plastic deformation, meaning an irreversible increase in length after removal of an applied stretching force, is a necessary condition for the wall-loosening reactions involved in growth (Hohl and Schopfer, 1992). Expansins and XTHs are CW-loosening agents that regulate $\mathrm{CW}$ expansion and cell enlargement through elastic deformation (Cosgrove, 2000; Miedes et al., 2013). The general down-regulation 
of $\alpha$-expansin and most XTHs genes in $V$. vinifera callus tissues observed in response to mineral stress are in line with the results obtained in extensibility tests, where no alteration in the elastic component of the deformations was observed.

Considering the gene expression results discussed above, it may be speculated that the lower proportion of hydrolytic enzymes found in the protein extracts under mineral stress conditions had less effect on the cucumber hypocotyl CWs polysaccharides. This feature may promote irreversible modifications in the physical properties due to mechanical, non-enzymatic effects. In fact, $\mathrm{XTH}$ $\mathrm{XEH}, \mathrm{GH} 9 \mathrm{C}$ and PME expressing in callus were among the genes with a more dramatic down-regulation, along with the reduced activity of endoglucanase under $-\mathrm{N}$, suggesting that the putative encoding enzymes are present at lower levels in the extracts applied to the inactivated dicot CW samples.

The use of ssNMR CW analyzes unraveled that less than $8 \%$ of cellulose surface is in contact with XyG (Bootten et al., 2004; Dick-Perez et al., 2011), with pectins filling the gaps. Pectins are presented as very dynamic polymers which due to their hydrophilic character may ease microfibrils motions as CW expands, reducing the direct cellulose-cellulose contacts (Park and Cosgrove, 2015). Instead of XyG, pectic monosaccharides (most likely from RG-I side chains galactan and arabinan rich (Zykwinska et al., 2007, 2008) may be associated to the cellulose (Cosgrove, 2014). Pectins can then serve as mechanical tethers between microfibrils (Wang et al., 2012; Peaucelle et al., 2012). Using the same system we had previously observed an increase in arabinose under $-\mathrm{N}$ conditions leading to $\mathrm{CW}$ reinforcement although still allowing significant plastic deformation (Fig. 4). These results agree with the presence of "biomechanical hotspots" as proposed by Park and Cosgrove (2012, 2015) in which wall extensibility is less dependent on the viscoelasticity of the matrix polymers depending more of the selective separation between microfibrils at limited CW sites.

The role of hydrolytic enzymes in CW loosening was formerly envisioned as the prime players in the expansion process (Farkas and Maclachlan, 1988; McDougall and Fry, 1990). Although it is not clearly acknowledged that they break glycosidic bonds of crystalline cellulose (Vissenberg et al., 2001; Cosgrove, 2005), it is recognized that their activity could contribute to the loosening of the CW, making it more pliable for expansion (Cosgrove, 2005). Park and Cosgrove (2012) reported that $\beta$-1,4-endo-glucanases may induce plastic deformation. This assumption agrees with our observations on the increase in endoglucanase activity and the increase in plastic deformation under $-\mathrm{P}$.

The results taken as a whole support the hypothesis that different mineral stresses impact different responses in the CW-related mechanisms that underlie development, with nitrogen effecting those responses more dramatically and sulfur leading to less pronounced responses. This may be due to the vital role of nitrogen in plant metabolism. In fact, as key element in protein synthesis, nitrogen depletion can redirect the metabolism preventing protein compensation by other members of the same family.

\section{Acknowledgments}

The research was funded by Fundação para a Ciência e a Tecnologia (FCT) project PTDC/AGR-GPL/099624/2008, CBAA (PestOE/AGR/UI0240/2011) and Grant SFRH/BD/64047/2009 to JCF.

\section{References}

Arnold, K., Bordoli, L., Kopp, J., Schwede, T., 2006. The SWISS-MODEL workspace: a web-based environment for protein structure homology modelling Bioinformatics 22, 195-201, http://dx.doi.org/10.1093/bioinformatics/bti770. Baumann, M.J., Eklof, J.M., Michel, G., Kallas, A.M., Teeri, T.T., Czjzek, M., Brumer III, H., 2007. Structural evidence for the evolution of xyloglucanase activity from xyloglucan endo-transglycosylases: biological implications for cell wall metabolism. Plant Cell 19, 1947-1963, http://dx.doi.org/10.1105/tpc.107. Bellincampi, D., Camardella, L., Delcour, J.A., Desseaux, V., D’Ovidio, R., Durand, A., Elliot, G., Gebruers, K., Giovane, A., Juge, N., Sorensen, J.F., Svensson, B., Vairo, D. 2004. Potential physiological role of plant glycosidase inhibitors. BBA Proteins Proteom. 1696, 265-274, http://dx.doi.org/10.1016/j.bbapap.2003.10.011.

Bootten, T.J., Harris, P.J., Melton, L.D., Newman, R.H., 2004. Solid-state ${ }^{13}$ C NMR spectroscopy shows that the xyloglucans in the primary cell walls of mung bean (Vigna radiata L.) occur in different domains: a new model for xyloglucan-cellulose interactions in the cell wall. J. Exp. Bot. 55, 571-583, http://dx.doi.org/10.1093/jxb/erh065.

Bosch, M., Hepler, P.K., 2005. Pectin methylesterases and pectin dynamics in pollen tubes. Plant Cell 17, 3219-3226, http://dx.doi.org/10.1105/tpc.105.037473.

Bradford, M.M., 1976. A rapid and sensitive method for the quantitation of microgram quantities of protein utilizing the principle of protein-dye binding. Anal. Biochem. 72, 248-254.

Braidwood, L., Breuer, C., Sugimoto, K., 2014. My body is a cage: mechanisms and modulation of plant cell growth. New Phytol. 201, 388-402, http://dx.doi.org/ 10.1111/nph.12473.

Brummell, D.A., Harpster, M.H., 2001. Cell wall metabolism in fruit softening and quality and its manipulation in transgenic plants. Plant Mol. Biol. 47, 311-340, http://dx.doi.org/10.1023/A.1010656104304.

del Campillo, E., Gaddam, S., Mettle-Amuah, D., Heneks, J., 2012. A tale of two tissues: AtGH9C1 is an endo- $\beta$-1,4-glucanase involved in root hair and endosperm development in Arabidopsis. PLoS One 7, e49363, http://dx.doi.org/ 10.1371/journal.pone.0049363.

Carpita, N., Tierney, M., Campbell, M., 2001. Molecular biology of the plant cell wall: searching for the genes that define structure, architecture and dynamics. Plant Mol. Biol. 47, 1-5, http://dx.doi.org/10.1023/A.1010603527077.

Chevenet, F., Brun, C., Banuls, A.L., Jacq, B., Chisten, R., 2006. TreeDyn: towards dynamic graphics and annotations for analyses of trees. BMC Bioinf. 7, 439, http://dx.doi.org/10.1186/1471-2105-7-439.

Choi, D., Cho, H.T., Lee, Y., 2006. Expansins expanding importance in plant growth and development. Physiol. Plant. 126, 511-518, http://dx.doi.org/10.1111/j. 1399-3054.2006.00612.x.

Coito, J.L., Rocheta, M., Carvalho, L., Amâncio, S., 2012. Microarray-based uncovering reference genes for quantitative real time PCR in grapevine under abiotic stress. BMC Res. Notes 5, 220, http://dx.doi.org/10.1186/1756-0500-5 220.

Cosgrove, D.J., 1993. How do plant cell walls extend? Plant Physiol. 102, 1-6.

Cosgrove, D.J., 1999. Enzymes and other agents that enhance cell wall extensibility. Annu. Rev. Plant Physiol. Plant Mol. Biol. (50), 391-417, http://dx.doi.org/10. 1146/annurev.arplant.50.1.391.

Cosgrove, D.J., 2000. Loosening of plant cell walls by expansins. Nature 407 , 321-326, http://dx.doi.org/10.1038/35030000.

Cosgrove, D.J., 2005. Growth of the plant cell wall. Nat. Rev. Mol. Cell Biol. 6, $850-861$.

Cosgrove, D.J., Jarvis, M.C., 2012. Comparative structure and biomechanics of plant primary and secondary cell walls. Front. Plant Sci. 3 (204), http://dx.doi.org/10. 3389/fpls.2012.00204.

Cosgrove, D.J., 2014. Re-constructing our models of cellulose and primary cell wall assembly. Curr. Opin. Plant Biol. 22, 122-131, http://dx.doi.org/10.1016/j.pbi. 2014.11.001.

Derbyshire, P., McCann, M.C., Roberts, K., 2007. Restricted cell elongation in Arabidopsis hypocotyls is associated with a reduced average pectin esterification level. BMC Plant Biol. 7, 31, http://dx.doi.org/10.1186/14712229-7-31.

Desprez, T., Juraniec, M., Crowell, E.F., Jouy, H., Pochylova, Z., Parcy, F., Höfte, H. Gonneau, M., Vernhettes, S., 2007. Organization of cellulose synthase complexes involved in primary cell wall synthesis in Arabidopsis thaliana. Proc. Natl. Acad. Sci. U. S. A. 104, 15572-15577, http://dx.doi.org/10.1073/pnas. 0706569104.

Di Matteo, A., Giovane, A., Raiola, A., Camardella, L., Bonivento, D., De Lorenzo, G., Cervone, F., Bellincampi, D., Tsernoglou, D., 2005. Structural basis for the interaction between pectin methylesterase and a specific inhibitor protein. Plant Cell 17, 849-858, http://dx.doi.org/10.1105/tpc.104.028886.

Dick-Perez, M., Zhang, Y., Hayes, J., Salazar, A., Zabotina, O.A., Hong, M., 2011. Structure and interactions of plant cell-wall polysaccharides by two- and three-dimensional magicangle-spinning solid-state NMR. Biochemistry 50 , 989-1000, http://dx.doi.org/10.1021/bi101795q.

Doblin, M.S., Pettolino, F., Bacic, A., 2010. Plant cell walls: the skeleton of the plant world. Funct. Plant Biol. 37, 357-381 http://dx.doi.org/10.1071/FP09279.

Durbin, M.L., Lewis, L.N., 1988. Cellulases in Phaseolus vulgaris. Methods Enzymol. 160, 342-351, http://dx.doi.org/10.1016/0076-6879(88)60137-6.

Edgar, R., 2004a. MUSCLE: a multiple sequence alignment method with reduced time and space complexity. BMC Bioinf. 5, 113, http://dx.doi.org/10.1186 1471-2105-5-113.

Edgar, R.C., 2004b. MUSCLE: multiple sequence alignment with high accuracy and high throughput. Nucleic Acids Res. 32, 1792-1797, http://dx.doi.org/10.1093/ nar/gkh340.

Eklöf, J.M., Brumer, H., 2010. The XTH: gene family: an update on enzyme structure, function, and phylogeny in xyloglucan remodeling. Plant Physiol 153, 456-466, http://dx.doi.org/10.1104/pp.110.156844.

Endler, A., Persson, S., 2011. Cellulose synthases and synthesis in Arabidopsis. Mol. Plant 4, 199-211, http://dx.doi.org/10.1093/mp/ssq079. 
Farkas, V., Maclachlan, G., 1988. Stimulation of pea 1,4- $\beta$-glucanase activity by oligosaccharides derived from xyloglucan. Carbohydr. Res. 184, 213-219. Farrokhi, N., Burton, R.A., Brownfield, L., Hrmova, M., Wilson, S.M., Bacic, A., Fincher, G.B., 2006. Plant cell wall biosynthesis: genetic, biochemical and functional genomics approaches to the identification of key genes. Plant Biotechnol. J. 4, 145-167, http://dx.doi.org/10.1111/j.1467-7652.2005.00169.x.

Fernandes, J.C., García-Angulo, P., Goulao, L.F., Acebes, J.L., Amâncio, S., 2013. Mineral stress affects the cell wall composition of grapevine (Vitis vinifera L.) callus. Plant Sci. 205-206, 111-120, http://dx.doi.org/10.1016/j.plantsci.2013. 01.013.

Fujita, M., Himmelspach, R., Hocart, C.H., Williamson, R.E., Mansfield, S.D., Wasteneys, G.O., 2011. Cortical microtubules optimize cell-wall crystallinity to drive unidirectional growth in Arabidopsis. Plant J. 66, 915-928, http://dx.doi. org/10.1111/j.1365-313X.2011.04552.x.

Giovannoni, J.J., 2004. Genetic regulation of fruit development and ripening. Plant Cell 16 (Suppl), S170-S180, http://dx.doi.org/10.1105/tpc.019158.

Glass, M., Barkwill, S., Unda, F., Mansfield, S.D., 2015. Endo- $\beta$-1,4-glucanases impact plant cell wall development by influencing cellulose crystallization. J. Integr. Plant Biol. 57, 396-410, http://dx.doi.org/10.1111/jipb.12353.

Goulao, L.F., 2010. Pectin de-esterification and fruit softening: revisiting a classical hypothesis. Stewart Postharvest Rev. 1,1-12, http://dx.doi.org/10.2212/spr. 2010.1.7.

Guex, N., Peitsch, M.C., 1997. SWISS-MODEL and the Swiss-Pdb viewer: an environment for comparative protein modeling. Electrophoresis 18 2714-2723, http://dx.doi.org/10.1002/elps.1150181505.

Guindon, S., Dufayard, J.-F., Lefort, V., Anisimova, M., Hordijk, W., et al., 2010. New algorithms and methods to estimate maximum-likelihood phylogenies: assessing the performance of PhyML 3.0. Syst. Biol. 59, 307-321, http://dx.doi org/10.1093/sysbio/syq010.

Handakumbura, P.P., Matos, D.A., Osmont, K.S., Harrington, M.J., Heo, K., Kafle, K., Kim, S.H., Baskin, T.I., Hazen, S.P., 2013. Perturbation of Brachypodium distachyon CELLULOSE SYNTHASE A4 or 7 results in abnormal cell walls. BMC Plant Biol. 13, 131, http://dx.doi.org/10.1186/1471-2229-13-131.

Hohl, M., Schopfer, P., 1992. Physical extensibility of maize coleoptile cell walls: apparent plastic extensibility is due to elastic hysteresis. Planta 187, 498-504, http://dx.doi.org/10.1007/BF00199968.

Hongo, S., Sato, K., Yokoyama, R., Nishitani, K., 2012. Demethylesterification of the primary wall by PECTIN METHYLESTERASE35 provides mechanical support to the Arabidopsis stem. Plant Cell 24, 2624-2634, http://dx.doi.org/10.1105/tpc. 112.099325.

Jackson, P., Galinha, C., Pereira, C., Fortunato, A., Soares, N., Amâncio, S., Pinto, C., 2001. Ricardo rapid deposition of extensin during the elicitation of grapevine callus cultures is specifically catalysed by a $40 \mathrm{kDa}$ peroxidase. Plant Physiol. 127, 1065-1076 http://dx.doi.org/10.1104/pp.01019.

Jaillon, O., Aury, J.M., Noel, B., Policriti, A., Clepet, C., Casagrande, A., Choisne, N., Aubourg, S., Vitulo, N., Jubin, C., et al., 2007. The grapevine genome sequence suggests ancestral hexaploidization in major angiosperm phyla. Nature 449 , 463-467, http://dx.doi.org/10.1038/nature06148.

Johansson, P., Brumer 3rd, H., Baumann, M.J., Kallas, A.M., Henriksson, H., Denman, S.E., Teeri, T.T., Jones, T.A., 2004. Crystal structures of a poplar xyloglucan endotransglycosylase reveal details of transglycosylation acceptor binding. Plant Cell 16, 874-886, http://dx.doi.org/10.1105/tpc.020065.

Jolie, R.P., Duvetter, T., Van Loey, A.M., Hendrickx, M.E., 2010. Pectin methylesterase and its proteinaceous inhibitor: a review. Carbohydr. Res. 345, 2583-2595, http://dx.doi.org/10.1016/j.carres.2010.10.002.

Juge, N., 2006. Plant protein inhibitors of cell wall degrading enzymes. Trends Plant Sci. 11, 359-367, http://dx.doi.org/10.1016/j.tplants.2006.05.006.

Kaewthai, N., Gendre, D., Eklöf, J.M., Ibatullin, F.M., Ezcurra, I., Bhalerao, R.P., Brumer, H., 2013. Group III-A XTH: genes of Arabidopsis encode predominant xyloglucan endohydrolases that are dispensable for normal growth. Plant Physiol. 161, 440-454, http://dx.doi.org/10.1104/pp.112.207308.

Lai-Kee-Him, J., Chanzy, H., Muller, M., Putaux, J., Imai, T., Bulone, V., 2002. In vitro versus in vivo cellulose microfibrils from plant primary wall synthases: structural differences. J. Biol. Chem. 277, 36931-36939, http://dx.doi.org/10. 1074/jbc.M203530200.

Landrein, B., Hamant, O., 2013. How mechanical stress controls microtubule behavior and morphogenesis in plants: history, experiments and revisited theories. Plant J. 75, 324-338, http://dx.doi.org/10.1111/tpj.12188.

Lerouxel, O., Cavalier, D.M., Liepman, A.H., Keegstra, K., 2006. Biosynthesis of plant cell wall polysaccharides-a complex process. Curr. Opin. Plant Biol. 9, 621-630, http://dx.doi.org/10.1016/j.pbi.2006.09.009.

Liners, F., Letesson, J.J., Didembourg, C., Van Cutsem, P., 1989. Monoclonal antibodies against pectin: recognition of a conformation induced by calcium. Plant Physiol. 91, 1419-1424 http://dx.doi.org/10.1104/pp.91.4.1419.

Malinovsky, F.G., Fangel, J.U., Willats, W.G.T., 2014. The role of the cell wall in plant immunity. Front. Plant Sci. 5 (178), http://dx.doi.org/10.3389/fpls.2014.00178.

Marcus, S.E., Verhertbruggen, Y., Hervé, C., Ordaz-Ortiz, J.J., Farkas, V., Pedersen, H.L., Willats, W.G.T., Knox, J.P., 2008. Pectic homogalacturonan masks abundant sets of xyloglucan epitopes in plant cell walls. BMC Plant Biol. 8, 60, http://dx.doi.org/10.1186/1471-2229-8-60.

Markovic, O., Janecek, S., 2004. Pectin methylesterases: sequence-structural features and phylogenetic relationships. Carbohydr. Res. 339, 2281-2295, http://dx.doi.org/10.1016/j.carres.2004.06.023.

Markovic, O., Kohn, R., 1984. Mode of pectin deesterification in Trichodrema reesei pectinesterese. Experientia 5, 842-843.
Matsui, A., Yokoyama, R., Seki, M., Ito, T., Shinozaki, K., Takahashi, T., Komeda, Y., Nishitani, K., 2005. AtXTH27 plays an essential role in cell wall modification during the development of tracheary elements. Plant J. 42, 525-534, http://dx. doi.org/10.1111/j.1365-313X.2005.02395.x.

McDougall, G.J., Fry, S.C., 1990. Xyloglucan oligosaccharides promote growth and activate cellulase. Evidence for a role of cellulase in cell expansion. Plant Physiol. 93, 1042-1048 http://dx.doi.org/10.1104/pp.93.3.1042.

McQueen-Mason, S., Durachko, D.M., Cosgrove, D.J., 1992. Two endogenous proteins that induce cell wall extension in plants. Plant Cell 4, 1425-1433 http://dx.doi.org/10.1105/tpc.4.11.1425.

McQueen-Mason, S.J., Cosgrove, D.J., 1995. Expansin mode of action on cell walls analysis of wall hydrolysis, stress relaxation and binding. Plant Physiol. 107, 87-100 http://dx.doi.org/10.1104/pp.107.1.87.

Micheli, F., 2001. Pectin methylesterases: cell wall enzymes with important roles in plant physiology. Trends Plant Sci. 6, 414-419, http://dx.doi.org/10.1016/ s1360-1385(01) 02045-3.

Miedes, E., Herbers, K., Sonnewald, U., Lorences, E.P., 2010. Overexpression of a cell wall enzyme reduces xyloglucan depolymerization and softening of transgenic tomato fruits. J. Agric. Food Chem. 58, 5708-5713, http://dx.doi.org/10.1021/ jf100242z.

Miedes, E., Suslov, D., Vandenbussche, F., Kenobi, K., Ivakov, A., Van Der Straeten, D., et al., 2013. Xyloglucan endotransglucosylase/hydrolase (XTH) overexpression affects growth and cell wall mechanics in etiolated Arabidopsis hypocotyls. J. Exp. Bot. 64, 2481-2497.

Murashige, T., Skoog, F., 1962. A revised medium for rapid growth and bioassays with tobacco tissue. Physiol. Plant. 15, 493-497, http://dx.doi.org/10.1111/j. 1399-3054.1962.tb08052.x.

Nicol, F., His, I., Jauneau, A., Vernhettes, S., Canut, H., Höfte, H., 1998. A plasma membrane-bound putative endo-1,4-beta-D-glucanase is required for normal wall assembly and cell elongation in Arabidopsis. EMBO J. 17, 5563-5576, http://dx.doi.org/10.1093/emboj/17.19.5563.

Oliveros, J.C., 2007. VENNY: an interactive tool for comparing lists with Venn Diagrams, http://bioinfogp.cnb.csic.es/tools/venny/index.html.

Osato, Y., Yokoyama, R., Nishitani, K., 2006. A principal role for AtXTH18 in Arabidopsis thaliana root growth-a functional analysis using RNAi plants. J. Plant Res. 119, 153-162, http://dx.doi.org/10.1007/s10265-006-0262-6.

Park, Y.B., Cosgrove, D.J., 2012. A revised architecture of primary cell walls based on biomechanical changes induced by substrate-specific endoglucanases. Plant Physiol. 158, 1933-1943, http://dx.doi.org/10.1104/pp.111.192880.

Park, Y.B., Cosgrove, D.J., 2015. Xyloglucan and its interactions with other components of the growing cell wall. Plant Cell Physiol. 56, 180-194, http://dx. doi.org/10.1093/pcp/pcu204.

Peaucelle, A., Louvet, R., Johansen, J.N., Hofte, H., Laufs, P., Pelloux, J., Mouille, G. 2008. Arabidopsis phyllotaxis is controlled by the methyl-esterification status of cell-wall pectins. Curr. Biol. 18, 1943-1948, http://dx.doi.org/10.1016/j.cub. 2008.10.065.

Peaucelle, A., Braybrook, S.A., Le Guillou, L., Bron, E., Kuhlemeier, C., Höfte, H., 2011. Pectin-induced changes in cell wall mechanics underlie organ initiation in Arabidopsis. Curr. Biol. 21, 1720-1726, http://dx.doi.org/10.1016/j.cub.2011.08. 057.

Peaucelle, A., Braybrook, S., Hofte, H., 2012. Cell wall mechanics and growth control in plants: the role of pectins revisited. Front. Plant Sci. 3, 121, http://dx. doi.org/10.3389/fpls.2012.00121.

Pelloux, J., Rustérucci, C., Mellerowicz, E.J., 2007. New insights into pectin methylesterase structure and function. Trends Plant Sci. 12, 267-277, http:// dx.doi.org/10.1016/j.tplants.2007.04.001.

Petersen, T.N., Brunak, S., von Heijne, G., Nielsen, H., 2011. SignalP 4.0: discriminating signal peptides from transmembrane regions. Nat. Methods 8 , 785-786, http://dx.doi.org/10.1038/nmeth.1701.

Pilling, E., Höfte, H., 2003. Feedback from the wall. Curr. Opin. Plant Biol. 6 , 611-616, http://dx.doi.org/10.1016/j.pbi.2003.09.004.

Popper, Z.A., Fry, S.C., 2005. Widespread occurrence of a covalent linkage between xyloglucan and acidic polysaccharides in suspension-cultured angiosperm cells. Ann. Bot. 96, 91-99, http://dx.doi.org/10.1093/aob/mci153.

Potters, G., Pasternak, T.P., Guisez, Y., Palme, K.J., Jansen, M.A.K., 2007. Stress-induced morphogenic responses: growing out of trouble? Trends Plant Sci. 12, 98-105, http://dx.doi.org/10.1016/j.tplants.2007.01.004.

Quevillon, E., Silventoinen, V., Pillai, S., Harte, N., Mulder, N., Apweiler, R., Lopez, R., 2005. InterProScan. protein domains identifier. Nucleic Acids Res. 33, W116-W120, http://dx.doi.org/10.1093/nar/gki442 (Web Server issue).

Reid, K.E., Olsson, N., Schlosser, J., Peng, F., Lund, S.T., 2006. An optimized grapevine RNA isolation procedure and statistical determination of reference genes for real-time RT-PCR during berry development. BMC Plant Biol. 6, 27, http://dx doi.org/10.1186/1471-2229-6-27.

Richmond, P.A., Métraux, J.P., Taiz, L., 1980. Cell expansion patterns and directionality of wall mechanical properties in nitella. Plant Physiol. 65, 211-217, http://dx.doi.org/10.1104/pp.65.2.211.

Richmond, T.A., Somerville, C.R., 2000. The cellulose synthase superfamily. Plant Physiol. 124, 495-498, http://dx.doi.org/10.1104/pp.124.2.495.

Saeed, A.I., Sharov, V., White, J., Li, J., Liang, W., Bhagabati, N., Braisted, J., Klapa, M., Currier, T., Thiagarajan, M., Sturn, A., Snuffin, M., Rezantsev, A., Popov, D. Ryltsov, A., Kostukovich, E., Borisovsky, I., Liu, Z., Vinsavich, A., Trush, V., Quackenbush, J., 2003. TM4: a free, open-source system for microarray data management and analysis. Biotechniques 34, 374-378.

Sampedro, J., Pardo, B., Gianzo, C., Guitián, E., Revilla, G., Zarra, I., 2010. Lack of $\alpha$-xylosidase activity in Arabidopsis alters xyloglucan composition and results 
in growth defects. Plant Physiol. 154, 1105-1115, http://dx.doi.org/10.1104/ pp.110.163212.

Sampedro, J., Gianzo, C., Iglesias, N., Guitián, E., Revilla, G., Zarra, I., 2012. AtBGAL10 is the main xyloglucan $\beta$-galactosidase in Arabidopsis, and its absence results in unusual xyloglucan subunits and growth defects. Plant Physiol. 158 1146-1157, http://dx.doi.org/10.1104/pp.111.192195.

Sato, S., Kato, T., Kakegawa, K., et al., 2001. Role of the putative membrane-bound endo-1,4-beta-glucanase KORRIGAN in cell elongation and cellulose synthesis in Arabidopsis thaliana. Plant Cell Physiol. 42, 251-263, http://dx.doi.org/10. 1093/pcp/pce045.

Scognamiglio, M.A., Ciardiello, M.A., Tamburrini, M., Carratore, V., Rausch, T. Camardella, L., 2003. The plant invertase inhibitor shares structural properties and disulfide bridges arrangement with the pectin methylesterase inhibitor. J. Protein Chem. 22, 363-369.

Somerville, C., 2006. Cellulose synthesis in higher plants. Annu. Rev. Cell Dev. Biol. 22, 53-78, http://dx.doi.org/10.1146/annurev.cellbio.22.022206.160206.

Suzuki, S., Li, L., Sun, Y.H., Chiang, V.L., 2006. The cellulose synthase gene superfamily and biochemical functions of xylem-specific cellulose synthase-like genes in Populus trichocarpa. Plant Physiol. 142, 1233-1245, http://dx.doi.org/10.1104/pp.106.086678.

Takahashi, J., Rudsander, U.J., Hedenström, M., Banasiak, A., Harholt, J., Amelot, N. Immerzeel, P., Ryden, P., Endo, S., Ibatullin, F.M., Brumer, H., del Campillo, E., Master, E.R., Scheller, H.V., Sundberg, B., Teeri, T.T., Mellerowicz, E.J., 2009. KORRIGAN1 and its aspen homolog PttCel9A1 decrease cellulose crystallinity in Arabidopsis stems. Plant Cell Physiol. 50, 1099-1115, http://dx.doi.org/10. 1093/pcp/pcp062.

Takeda, T., Furuta, Y., Awano, T., Mizuno, K., Mitsuishi, Y., Hayashi, T., 2002. Suppression and acceleration of cell elongation by integration of xyloglucans in pea stem segments. Proc. Natl. Acad. Sci. U. S. A. 99, 9055-9060, http://dx. doi.org/10.1073/pnas.132080299.

Talavera, G., Castresana, J., 2007. Improvement of phylogenies after removing divergent and ambiguously aligned blocks from protein sequence alignments. Syst. Biol. 56, 564-577, http://dx.doi.org/10.1080/10635150701472164.

Taylor, N.G., Howells, R.M., Huttly, A.K., Vickers, K., Turner, S.R., 2003. Interactions among three distinct CesA proteins essential for cellulose synthesis. Proc. Natl. Acad. Sci. U. S. A. 100, 1450-1455, http://dx.doi.org/10.1073/pnas.0337628100.

Tenhaken, R., 2015. Cell wall remodeling under abiotic stress. Front. Plant Sci. 5, 771, http://dx.doi.org/10.3389/fpls.2014.00771.

Urbanowicz, B.R., Bennett, A.B., del Campillo, E., Catalá, C., Hayashi, T., Henrissat, B. Höfte, H., McQueen-Mason, S.J., Patterson, S.E., Shoseyov, O., Teeri, T.T., Rose, J.K., 2007a. Structural organization and a standardized nomenclature for plant endo-1,4-beta-glucanases (cellulases) of glycosyl hydrolase family 9. Plant Physiol. 144, 1693-1696 http://dx.doi.org/10.1104/pp.107.102574.

Urbanowicz, B.R., Catalá, C., Irwin, D., Wilson, D.B., Ripoll, D.R., Rose, J.K.C., 2007b. A tomato endo- $\beta-1,4$-glucanase, SICel9C1, represents a distinct subclass with a new family of carbohydrate binding modules (CBM49). J. Biol. Chem. 282, 12066-12074, http://dx.doi.org/10.1074/jbc.M607925200.

Vain, T., Crowell, E.F., Timpano, H., Biot, E., Desprez, T., Mansoori, N., Trindade, L.M. Pagant, S., Robert, S., Höfte, H., Gonneau, M., Vernhettes, S., 2014. The cellulase KORRIGAN: is part of the cellulose synthase complex. Plant Physiol. 165 1521-1532 httsp://dx.doi.org/10.1104/pp.114.241216.

Van Sandt, V.S., Suslov, D., Verbelen, J.P., Vissenberg, K., 2007. Xyloglucan endotransglucosylase activity loosens a plant cell wall. Ann. Bot. 100 1467-1473, http://dx.doi.org/10.1093/aob/mcm248.
Velasco, R., Zharkikh, A., et al., 2007. A high quality draft consensus sequence of the genome of a heterozygous grapevine variety. PLoS One 2, e1326, http://dx.doi. org/10.1371/journal.pone.0001326.

Vissenberg, K., Fry, S.C., Verbelen, J.-P., 2001. Root hair initiation is coupled to a highly localized increase of xyloglucan endotransglycoslyase action in Arabidopsis roots. Plant Physiol. 127, 1125-1135, http://dx.doi.org/10.1104/pp. 010295.

Wakabayashi, K., Soga, K., Kamisaka, S., Hoson, T., 2003. Modification of cell wall architecture of wheat coleoptiles grown under hypergravity conditions. Biol. Sci. Space 17, 228-229.

Wang, T., Zabotina, O., Hong, M., 2012. Pectin-cellulose interactions in the Arabidopsis primary cell wall from two-dimensional magic-angle-spinning solid-state nuclear magnetic resonance. Biochemistry 51, 9846-9856, http:// dx.doi.org/10.1021/bi3015532.

Wang, T., Park, Y.B., Caporini, M.A., Rosay, M., Zhong, L., Cosgrove, D.J., Hong, M., 2013. Sensitivity-enhanced solid-state NMR detection of expansin's target in plant cell walls. Proc. Natl. Acad. Sci. U. S. A. 110, 16444-16449, http://dx.doi. org/10.1073/pnas.1316290110.

Whitney, S.E.C., Gidley, M.J., McQueen-Mason, S.J., 2000. Probing expansin action using cellulose/hemicellulose composites. Plant J. 22, 327-334, http://dx.doi. org/10.1046/j.1365-313x.2000.00742.x.

Willats, W.G., Gilmartin, P.M., Mikkelsen, J.D., Knox, J.P., 1999. Cell wall antibodies without immunization: generation and use of de-esterified homogalacturonan block-specific antibodies from a naive phage display library. Plant J. 18, 57-65, http://dx.doi.org/10.1046/j.1365-313X.1999.00427.x.

Willats, W.G.T., Orfila, C., Limberg, G., Buchholt, H.C., van Alebeek, G.J.W.M. Voragen, A.G.J., Marcus, S.E., Christensen, T.M.I.E., Mikkelsen, J.D., Murray, B.S., Knox, J.P., 2001. Modulation of the degree and pattern of methyl-esterification of pectic homogalacturonan in plant cell walls. Implications for pectin methyl esterase action, matrix properties, and cell adhesion. J. Biol. Chem. 276 , 19404-19413, http://dx.doi.org/10.1074/jbc.M011242200.

Wilson, M.H., Holman, T.J., Sorensen, I., Cancho-Sanchez, E., Wells, D.M., Swarup, R., et al., 2015. Multi-omics analysis identifies genes mediating the extension of cell walls in the Arabidopsis thaliana root elongation zone. Front. Cell Dev. Biol. 3, 10, http://dx.doi.org/10.3389/fcell.2015.00010.

Wolf, S., Mravec, J., Greiner, S., Mouille, G., Höfte, H., 2012. Plant cell wall homeostasis is mediated by brassinosteroid feedback signaling. Curr. Biol. 22 1732-1737, http://dx.doi.org/10.1016/j.cub.2012.07.036.

Yuan, S., Wu, Y., Cosgrove, D.J., 2001. A fungal endoglucanase with plant cell wall extension activity. Plant Physiol. 127, 324-333, http://dx.doi.org/10.1104/pp. 127.1.324.

Zykwinska, A., Ralet, M.C., Garnier, C., Thibault, J.F., 2005. Evidence for in vitro binding of pectic side chains to cellulose. Plant Physiol. 139, 397-407, http:/ dx.doi.org/10.1104/pp.105.065912.

Zykwinska, A., Thibault, J.-F., Ralet, M.-C., 2007. Organization of pectic arabinan and galactan side chains in association with cellulose microfibrils in primary cell walls and related models envisaged. J. Expl. Bot. 58, 1795-1802, http://dx. doi.org/10.1093/jxb/erm037.

Zykwinska, A., Thibault, J.F., Ralet, M.C., 2008. Competitive binding of pectin and xyloglucan with primary cell wall cellulose. Carbohydr. Polym. 74, 957-961, http://dx.doi.org/10.1016/j.carbpol.2008.05.004. 